\title{
Notes and Announcements
}

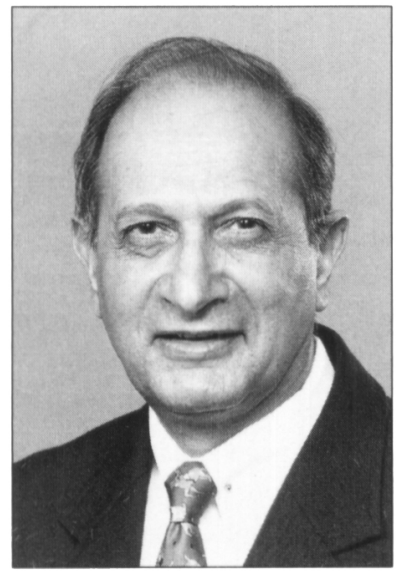

\section{Order of Canada for Ali Rajput}

On July 1, 1997, Dr. Ali Hasan

Rajput received an award of officer, Order of Canada. He thus joins the very small elite group of Canadian physicians who have been awarded this honour. He also received the Saskatchewan Order of Merit in 1993 which is the highest provincial award.

Dr. Rajput obtained his medical degree from the Liaquat Medical College in Sind, Pakistan and graduated in 1958. After completing his internship and year of practice in Sanghar, Pakistan, came to the United States and did his specialty training in neurology and an MSc in neurology at the University of Michigan in Ann Arbor. He joined the Faculty of Medicine, University of Saskatchewan on July 1, 1967 and has been with the College of Medicine in Saskatoon since then.

Dr. Rajput has a distinguished career as a teacher, clinician and a researcher. He has published alone or co-authored more than 300 scientific publications/presentations. Several of them have won special recognition. He co-founded the Saskatchewan Parkinson Disease Foundation and Movement Disorder Group of Canada and was recently appointed to serve on the World Health Organization working group on Parkinsons Disease. He is the only Canadian on this World Health Organization group. Dr. Rajput sits on the Medical Advisory Committees of several national and international agencies, is on editorial boards of several scientific journals and is scientific reviewer for over a dozen medical journals.

$$
* * * * * * *
$$

\section{The Canadian Society of Clinical Neurophysiologists EEG and EMG Examinations}

June 15-16, 1998

Canadian Society of Clinical Neurophysiologists (CSCN) will be accepting applications for the 1998 Canadian Electroencephalography Examination which will be held in

Montreal, PQ. The written exam will take place on June 15 th and the oral exam will be held on June 16th, location to be determined. Deadline for receipt of application and fee is April 1, 1998. Send applications to Dr. Richard Desbiens, CSCN Examining Committee (EEG), c/o Canadian Congress of Neurological Sciences, Suite 810, 906 - 12th Avenue SW, Calgary, Alberta, Canada T2R 1K7. For additional information, contact Dr. Richard Desbiens at Fax: (418) 649-5915 or email: richard.desbiens@compuserve.com.

Canadian Society of Clinical Neurophysiologists (CSCN) will be accepting applications for the 1998 Canadian Electromyography Examination which will be held in Montreal, PQ. The exam will take place on Saturday, June 20, 1998 at St-Luc's Hospital. Deadline for receipt of application and fee of $\$ 100.00$ is January 15 , 1998. Send applications to Dr. François Grand'Maison, CSCN Examining Committee (EMG), c/o Canadian Congress of Neurological Sciences, Suite 810, 906 - 12th Avenue SW, Calgary, Alberta, Canada T2R 1K7. For additional information, contact the CCNS Secretariat at Tel: (403) 229-9544 or Email at brains@ccns.org.

The following individuals were successful in completing their examinations in EEG and EMG.
EEG examination in 1996:
EEG examination in 1997:
EMG examination in 1996:
N. Mullatti, D. Cameron
P. Pathak
M. Ali Al-Jumal, R. Burnham,
B. Guppy, J. Kay, G. Midroni,
J. Mununthan, K. Stolee, S. Tremblay, C. Voll
$* * * * * * *$

\section{Society Awards}

Philip Porter

Ian Parney

David Houlden

Brenda Banwell
The K.G. McKenzie Prize for Clinical Neurosciences Research

The K.G. McKenzie Prize for Basic Neuroscience Research

The Herber Jasper Prize

The President's Prize

\section{Errata}

In Volume 24, Number 2, 1997, page 171, the price for the book entitled "Balance Disorders: A Case-Study Approach" should be $\$ \mathrm{C} 105.95$. On page 176, the price for the book entitled "Pain Management; Theory and Practice" should be $\$ \mathrm{Cl} 141.95$. On page
172 , the title specific information for the book entitled "A Guide to Adult Neuropsychological Diagnosis" should be as follows: First Edition. 1996. By Anthony Y. Stringer. Published by F.A. Davis Company, Philadelphia. 510 pages. $\$ C 100.50$. 